\title{
Biomass-burning-induced surface darkening and its impact on regional meteorology in eastern China
}

\author{
Rong Tang ${ }^{1,2}$, Xin Huang ${ }^{1,2}$, Derong Zhou ${ }^{1,2}$, and Aijun Ding ${ }^{1,2}$ \\ ${ }^{1}$ School of Atmospheric Sciences, Nanjing University, Nanjing, 210023, China \\ ${ }^{2}$ Collaborative Innovation Center of Climate Change, Jiangsu Province, Nanjing, 210023, China
}

Correspondence: Xin Huang (xinhuang@nju.edu.cn)

Received: 18 October 2019 - Discussion started: 10 December 2019

Revised: 18 April 2020 - Accepted: 28 April 2020 - Published: 27 May 2020

\begin{abstract}
Biomass burning has attracted great concerns for the emission of particular matters and trace gases, which substantially impacts air quality, human health, and climate change. Meanwhile, large areas of dark char, carbon residue produced in incomplete combustion, can stick to the surface over fire-prone areas after open burning, leading to a sharp drop in surface albedo, so-called "surface darkening". However, exploration into such surface albedo declines and the radiative and meteorological effects is still fairly limited. As one of the highest-yield agricultural areas, eastern China features intensive straw burning every early summer, the harvest season for winter wheat, which was particularly strong in 2012. Satellite retrievals show that the surface albedo decline over fire-prone areas was significant, especially in the near-infrared band, which can reach -0.16 . Observational evidence of abnormal surface warming was found by comparing radiosonde and reanalysis data. Most sites around intensive burned scars show a positive deviation, extending especially in the downwind area. Comparisons between "pre-fire" and "post-fire" from 2007 to 2015 indicated a larger temperature bias of the forecast during the post-fire stage. The signal becomes more apparent between 14:00 and 20:00 LT. Weather Research and Forecasting model coupled with Chemistry (WRF-Chem) simulations suggest that including surface darkening can decrease model bias and wellcaptured temperature variation after burning at sites in fire areas and their adjacent area. This work highlights the importance of biomass burning induced albedo change in weather forecast and regional climate.
\end{abstract}

\section{Introduction}

Biomass burning (BB) refers to open or quasi-open combustion of plants or organic fuels, including forest fires, savannah fires, peat burning, and crop residue burning in fields (Andreae, 1991; Andreae and Merlet, 2001; Fearnside, 2000; Thompson, 1996). Intensive BB events occur across the world every year and pose great threats to life and the property of human beings (Bowman and Panton, 1994; Duncan et al., 2003; Kaiser et al., 2012; Streets et al., 2003; Uhl and Kauffman, 1990). Apart from this, BB has received widespread attention due to air pollution, health threats, and climate change caused by the large amount of particulate matter, trace gases, and greenhouse gases it releases (Chan and Yao, 2008; Chang and Song, 2010; Chen et al., 2017; Crutzen and Andreae, 1990; Crutzen et al., 1979; Hansen et al., 2005; Haywood and Ramaswamy, 1998; Hobbs et al., 1997; Langmann et al., 2009; Podgorny et al., 2003). However, the impact of BB is much more than that. BB can directly destruct vegetation covers and affect soil properties over fire-prone areas (Certini, 2005), and it is considered as one of the most important factors influencing the global terrestrial ecosystem (Fearnside, 2000).

Since open BB tends to occur directly on land surface, vegetation covers will be destructed, and the underlying surface properties will be affected straightway (Certini, 2005; Myhre et al., 2005). Among them, surface albedo is highly sensitive to BB (Jin and Roy, 2005). Due to the cover of black charcoal produced in incomplete combustion, sharp surface albedo decline can be observed over fire-prone areas, which has been proven on several kinds of vegetation covers, including savannah and forest (Govaerts et al., 2002; Jin and 
Roy, 2005; Myhre et al., 2005; Roy and Landmann, 2005). This kind of "surface darkening" can last for about 1 week or even longer if it is dryer and calmer, before char materials are removed by weathering and vegetation starts to regenerate (Amiro et al., 2006; Beringer et al., 2003; Bremer and Ham, 1999; Trigg and Flasse, 2000; Tsuyuzaki et al., 2008; Veraverbeke et al., 2012). The magnitude of such surface albedo decline depends on fire intensity and can be up to half of pre-fire values (Veraverbeke et al., 2012). Decreased surface albedo enhances the capacity of fire-affected surface to absorb solar radiation under clear-sky conditions, perturbing the surface energy budget and the process of landatmosphere interaction, and then modifying local or even regional circulation (Gatebe et al., 2014). These changes in meteorological parameters will be important for weather and air quality forecast (Ding et al., 2013a; Yang et al., 2019; Zhang et al., 2016).

Though restrictions have been imposed, severe and largescale BB events still occurred frequently all over the world in recent years (Abatzoglou and Williams, 2016; Nolan et al., 2020). Moreover, threats from global fire activities are still increasing dramatically with climatic and anthropogenic drivers (Marlon et al., 2009; Pechony and Shindell, 2010; Van Der Werf et al., 2006). These facts emphasize the urgent need for further research on the impact of BB, to improve the human ability to predict future weather and climate (Hansen et al., 2005). Globally, BB events occur with significant seasonal variations and distinct regional characteristics (Duncan et al., 2003; Hao and Liu, 1994; Kaiser et al., 2012; Streets et al., 2003; Uhl and Kauffman, 1990). It is noteworthy that agricultural burning is still very common in many developing countries, mainly during post-harvest periods, for the purpose of clearing farmland and providing ash fertilization for the crop rotation (Gao, 2002; Ravindra et al., 2019; Tipayarom and Kim Oanh, 2020). However, exploration into such fire-induced decreased surface albedo and its radiative and meteorological effects is still fairly limited.

As for China, with the world's top-ranked crop production across the world, about $122 \mathrm{Tg}$ of crop residue is burned on site annually (Yan et al., 2006). Eastern China, especially the middle and lower reaches of the Yellow River and Yangtze River, features a large plain area and dense population with high agricultural production (Li et al., 2016). Eastern China has been characterized by intensive straw burning every June, the harvest season for winter wheat (He et al., 2007; Huang et al., 2012a, 2018; Li et al., 2016; Yang et al., 2013; Yin et al., 2019). After revolution in rural fuel structure, farmers, who are eager to deal with tons of wheat straw, always resort to burning on site rather than taking it as fuel (Lu et al., 2011; Yan et al., 2006; Zhu et al., 2019). Hence, the wheat straw burning is exceedingly dense in both time and space (Huang et al., 2012b; Yang et al., 2008). This phenomenon not only poses alarming threats to air quality and human health (Ding et al., 2016; Nie et al., 2015) but also brings great challenges to weather and climate forecast (Ding et al., 2013b; Huang et al., 2016; Wang et al., 2018; Xu et al., 2018; Zhou et al., 2018).

Based on years of satellite fire counts in eastern China, the most severe straw burning happened in June 2012 (Huang et al., 2012b). The most concentrated area of burning in eastern China is the Yellow-Huai River area (YHR), which connects the middle and lower reaches of the Yellow River and Yangtze River. YHR is the major wheat-producing area in China (Lei and Yuan, 2013). An extremely typical pollution episode was triggered by BB emissions from YHR in June 2012, during which a yellow haze blanketed the Yangtze River Delta (YRD) (Ding et al., 2013a; Huang et al., 2012b; Xie et al., 2015). The intensive BB events and the resulting heavy pollution put weather forecast in trouble, during which a series of meteorological anomalies were observed, such as air temperature changes and precipitation redistribution (Ding et al., 2013a; Gao et al., 2018; Huang et al., 2016). On one hand, these anomalies have been partly attributed to aerosols, particularly absorbing aerosols like black carbon (BC), considering the interaction between air quality and meteorology (Huang et al., 2016). On the other hand, the fire-induced decreased surface albedo and its radiative and meteorological effects on a regional scale should not be ignored (Myhre et al., 2005). The striking spectral contrast between dark charcoal deposits over burned surface and bright ripe wheat could cause distinct physical signals, socalled surface darkening (Govaerts et al., 2002; Pereira et al., 1999). The influence of such surface albedo decline on the local and regional energy budget can be significant (Jin and Roy, 2005), especially in summer when solar radiation is extremely strong. It could be another key issue that needs to be well understood so as to figure out the meteorological anomalies during the burning season. Since many developing areas are still carrying out large-scale agricultural burning, better understanding of such fire-induced albedo change and its meteorological effects is of great significance for weather and climate forecast (Ravindra et al., 2019).

In this study, signals of surface albedo decline induced by crop residue burning in eastern China were found based on satellite retrievals, defined as surface darkening. The magnitude and spatial distribution of the declines were investigated combining fire counts by Moderate Resolution Imaging Spectroradiometer (MODIS) based on straw burning in June 2012. Temperature anomalies after BB were also explored using long-term site observations from 2007 to 2015 in eastern China, and comparisons were made between two statuses: "pre-fire" and "post-fire". Moreover, with the aid of the Weather Research and Forecasting model coupled with Chemistry (WRF-Chem model), decreased surface albedo over fire-prone areas were taken into consideration in the simulation targeting temperature anomalies in June 2012. The further impact of surface darkening on the radiation budget, energy reallocation in the Earth-atmosphere system, and meteorology were discussed on a local and regional scale, 
which is of assignable climatological significance and should not be neglected.

\section{Data and methods}

\subsection{Fire counts and surface albedo}

The intensity of fire counts and the magnitude of surface albedo decline induced by crop residue burning were analysed based on standard MODIS products provided by NASA (Giglio and Justice, 2015a, b; Vermote, 2015).

The MODIS Surface Reflectance product (MOD09A1) provides an estimate of the surface spectral reflectance of MODIS bands 1 through 7 at a horizontal resolution of $500 \mathrm{~m}$ and uses the Bidirectional Reflectance Distribution Function (BRDF) database to better constrain the different threshold used (Schaaf et al., 2002). Wavelengths of the seven MODIS spectral narrowbands range relatively from 0.62 to $0.67,0.84$ to $0.87,0.46$ to $0.48,0.54$ to $0.56,1.23$ to $1.25,1.63$ to 1.65 , and 2.11 to $2.15 \mu \mathrm{m}$. The narrowband albedo can be converted to specified broadband albedo for shortwave and nearinfrared broadband through valid algorithms (Liang, 2001; Liang et al., 2003). It has been corrected for atmospheric conditions such as gases, aerosols, and Rayleigh scattering. The dataset is updated every $8 \mathrm{~d}$, for selecting one value from all acquisitions in an $8 \mathrm{~d}$ composite period for each pixel unit. The criteria for grid cell value selection include cloud conditions and solar zenith angle.

The MODIS Thermal Anomalies/Fire Daily L3 Global product (MOD/MYD14A1) consists of daily surface thermal anomaly data obtained by Terra and Aqua satellites with spatial resolution of $1 \mathrm{~km}$ (Giglio et al., 2009, 2013, 2016; Hawbaker et al., 2008), and fire counts with low confidence were got rid of for quality control. The "fire count" described in the following part indicates the central location of MODIS pixels with surface thermal anomalies. The actual geographic size of the pixel varies depending on the angle at which a satellite scans. When counting the number of pixels in the target region, the pixels are abstracted into points on a twodimensional plane.

\subsection{Temperature observation and forecast}

To obtain the surface meteorological conditions, meteorological observations of air temperature at $2 \mathrm{~m}$ height were acquired from the Integrated Surface Dataset from the US National Centers for Environmental Information (NCEI). The temperature observations were used to compare with the US National Centers for Environmental Prediction (NCEP) global final analysis data (FNL) with a $1^{\circ} \times 1^{\circ}$ spatial resolution which is updated every $6 \mathrm{~h}$, and they were also applied for verification and analysis of numerical simulations.

The radiosonde data at Xuzhou $\left(34.28^{\circ} \mathrm{N}, 117.15^{\circ} \mathrm{E}\right.$; WMO station number 58027) were collected from the University of Wyoming (http://weather.uwyo.edu/upperair/ sounding.html, last access: 28 December 2019), which is the only sounding site in the YHR area. The radiosondes were launched twice a day (08:00 and 20:00 LT) and made measurements both on the mandatory pressure levels (e.g. surface, 1000,900 , and $850 \mathrm{hPa}$ ) and additional key levels. They measure vertical profiles of atmospheric parameters like air temperature and water mixing ratio.

\subsection{Experiment design and model configuration}

Version 3.6.1 of WRF-Chem, an online-coupled chemical transport model, was employed in this study, in which multiple physical and chemical processes are depicted, including emission, transport, mixing, and chemical transformation of trace gases and aerosols simultaneously with meteorology (Grell et al., 2005). In order to take fire-induced albedo change into consideration and figure out the impact of surface darkening on the radiation budget and meteorology in eastern China, a pair of parallel experiments in WRF-Chem with surface albedo as a variable were designed: in the control (CTL) experiment, a default value of monthly surface albedo in the model was adopted, while in the ABD experiment we applied satellite-detected albedo decline over fireprone areas. In particular, the fire-affected grids were extracted out by a certain threshold of fire count density in June 2012, and the surface albedo decline in each grid is defined as the difference between MODIS-detected surface albedo post-fire and pre-fire based on the satellite data analysis in Sect. 3.1. In YHR, most fire from wheat straw is characterized by short-lived and incomplete smoldering (Huang et al., 2016). The relationship between the fire radiative power (FRP) and fire sizes varies at a global scale, and FRP of such straw burning is much weaker than grassland fires in North American (Laurent et al., 2019). Based on the MODIS Thermal Anomalies product (MOD/MYD14A1), the average maximum FRP for the most severe burning area in June 2012 is almost less than $0.02 \mathrm{~kW} \mathrm{~m}^{-2}$, the energy disturbance of which is much smaller than the continuous radiative disturbance of surface albedo decline in summer. Consequently, the heat released by fire was not treated in the model.

The domain is centred at $33.0^{\circ} \mathrm{N}, 115.0^{\circ} \mathrm{E}$ with a grid resolution of $20 \mathrm{~km}$ covered the eastern China and its surrounding areas. The initial and lateral boundary conditions of meteorological variables are obtained from NCEP FNL, which updates every $6 \mathrm{~h}$. MIX, a mosaic Asian anthropogenic emission inventory developed by Tsinghua University ( $\mathrm{Li}$ et al., 2017), and the Fire Inventory from NCAR (FINN), providing high-resolution global emission estimates from open burning (Wiedinmyer et al., 2011), were applied in WRF-Chem as anthropogenic and BB emissions, respectively. The simulations were conducted for the time period of 2-18 June 2012 and split into eight independent $72 \mathrm{~h}$ runs for the meteorological fields, while the chemical outputs from the preceding run were used as the initial conditions for the following run. Only the last $48 \mathrm{~h}$ results of each run were kept for analysis, and 
Table 1. WRF-Chem domain setting and configuration selections.

\begin{tabular}{ll}
\hline Domain setting & \\
\hline Horizontal grids & $130 \times 130$ \\
Grid spacing & $20 \mathrm{~km} \times 20 \mathrm{~km}$ \\
Vertical layers & 30 \\
Map projection & Lambert conformal \\
\hline Configuration selections \\
\hline Land surface & Noah \\
Boundary layer & MYJ \\
Microphysics & Lin et al. \\
Cumulus & Grell-Freitas \\
Radiation & RRTMG \\
Chemistry & CBMZ \\
Aerosol & MOSAIC \\
\hline
\end{tabular}

the first $7 \mathrm{~d}$ were regarded as the model spin-up period for atmospheric chemistry, so as to allow the model to reach a state of statistical equilibrium under the applied forcing (Berge et al., 2001; Lo et al., 2008).

The main configurations for WRF-Chem physical and chemical processes in both CTL and ABD experiment are listed in Table 1. A new version of the rapid radiative transfer model for general circulation model applications (RRTMG) was employed to depict the radiative transfer process for both shortwave and longwave radiation (Iacono et al., 2008; Mlawer et al., 1997). The Noah land surface scheme (Ek et al., 2003) was used to describe the land-atmosphere interactions, implemented with the MYJ boundary Layer scheme (Janjic, 1994) to describe the diurnal evolution of the planet boundary layer (PBL). As for cloud and precipitation processes, the new Grell-Freitas cumulus ensemble parameterization (Grell and Freitas, 2014) along with Lin microphysics (Lin et al., 1983) accounting for six forms of hydrometers was employed. Moreover, since the experiments were designed on the basis of MODIS products, the MODIS surface classification options of the International GeosphereBiosphere Programme (IGBP) was adopted to keep consistency.

\section{Results and discussion}

\subsection{Fire-induced surface albedo change}

In 2012, About $160 \mathrm{Tg}$ of crop residue was burned, and $36 \%$ of the total fires were recorded on farmland, the majority of which occurred in June, the harvest season for wheat (Li et al., 2016). YHR, the major wheat-producing area in China, is located in the vast flat plain in eastern China. Figure 1a shows the daily number of satellite fire counts in YHR, where cropland, especially wheat, dominates the vegetation cover (Gong et al., 2019; Lei and Yuan, 2013; Van Der Werf et al., 2010). The limited duration of agricultural fire combined with the low temporal resolution of MODIS may increase the difficulty of signal capture and lead to underestimation of fire counts (Chang and Song, 2009, 2010; Giglio et al., 2009; Randerson et al., 2012; Yin et al., 2019). As illustrated in Fig. 1a, severe and intensive BB events happened in mid-early June, especially 7-13 June, a tense and busy period in the crop cycle for harvest of wheat and sowing of maize. Among them, burning on 13 June is the most serious. Black charcoal deposits produced in highly intensive open straw burning would adhere to exposed soil and bound surface albedo over a period of time before removal of the char by natural process or regeneration of vegetation (Veraverbeke et al., 2012). The strong spectral contrast between dark burned surface and original bright, dry ripe wheat cover can cause distinct physical signals (Govaerts et al., 2002; Pereira et al., 1999).

Understanding the saliency and persistence of signals is important for estimation of albedo change amplitude and further analysis of its radiative and meteorological effects. The signals of surface darkening were a relatively short duration of about 1 week and much more sensitivity in shortwave near-infrared bands (Trigg and Flasse, 2000). Considering higher resolution and better depiction of narrowband satellite observations, and the outstanding capacity of the nearinfrared band to separate the signals between vegetation and charcoal (Jin and Roy, 2005; Trigg and Flasse, 2000), the shortwave near-infrared band $(0.84-0.87 \mu \mathrm{m})$ was chosen. Figure $1 \mathrm{~b}$ and $\mathrm{c}$ show the surface albedo distribution before and after the severe burning separately, based on the MODIS Surface Reflectance product (MOD09A1), which updates every $8 \mathrm{~d}$ and has ruled out the interference of clouds. Data on 1 June have not been adopted because of too few valid data. For the shortwave near-infrared band, the decrease induced by fire is about 0.30 to 0.14 , almost half of original values. The immediate surface albedo decline after fire can be attributed to the large-scale replacement of ripe wheat with black charcoal over fire-prone areas, so-called "burned scar". Char materials strongly absorb the incoming solar radiation, causing a significant decline of the reflection-to-incomingsolar-radiation ratio (Veraverbeke et al., 2012), and this could disturb surface radiation balance at a level that cannot be ignored (Jin and Roy, 2005), which needs further exploration.

The total satellite-detected fire counts with highconfidence from 24 May to 17 June, the highly intensive straw burning period, are shown in Fig. 2a. Combined satellite-derived surface albedo changes of the same time period in the shortwave near-infrared broadband at fire locations are shown in Fig. 2b. As illustrated, the fire counts are fairly concentrated, especially in the northern part of Anhui (AH) province, an agricultural area mainly dominated by winter wheat (Yan et al., 2006). Correspondingly, extensive negative values in Fig. $2 \mathrm{~b}$ demonstrate substantial signals of surface albedo decline over fire-prone areas in June 2012. For the near-infrared broadband, the declines range from -0.16 to -0.02 . In addition, the surface albedo declines show ob- 

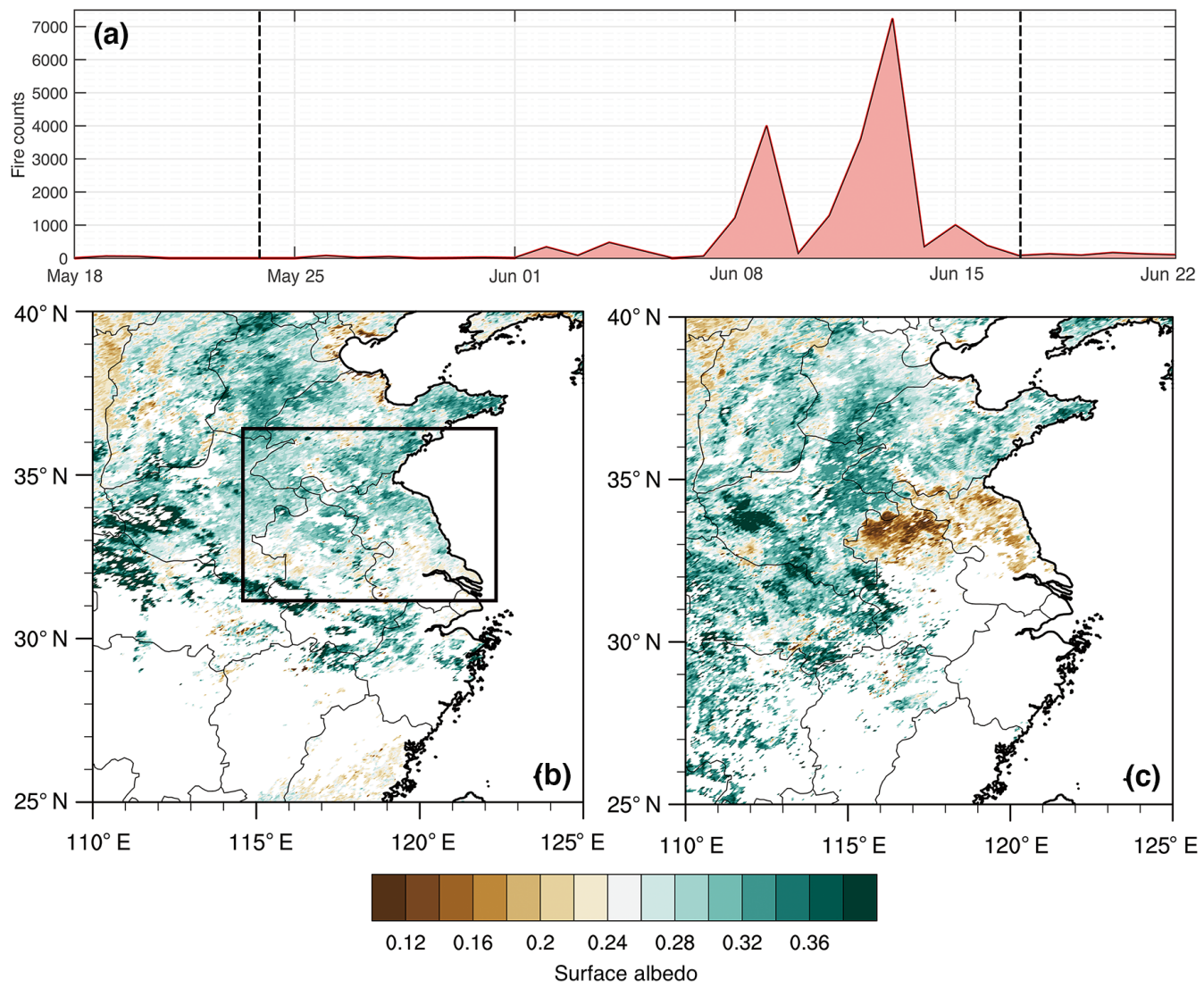

Figure 1. (a) Daily number of satellite fire counts in the black-boxed zone marked in panel (b). Distribution of satellite-retrieved surface albedo in the northern part of Anhui and Jiangsu provinces (b) on 24 May and (c) on 17 June in 2012. Note that the two dates are marked by black dashed lines in panel (a).

vious spatial heterogeneity and have a larger decline margin in northern AH than Jiangsu (JS). The effect of fire surface albedo is complex, determined by combustion completeness, fire intensity, pre-fire land cover structure, and underlying soil reflectance (Roy and Landmann, 2005). Here, the burning in $\mathrm{AH}$ was indeed more severe, which is consistent with the satellite fire detection. Though the surface albedo product applied here has ruled out cloud interference, inevitable noise from cloud shadow still exists, as reflected in the scattered positive values in the north-western region in Fig. $2 b$.

To better understand the signals of agricultural-fireinduced surface albedo decline and provide a basis for the following numerical experiments, frequency distributions of surface albedo decline in the near-infrared $(0.7-2.5 \mu \mathrm{m})$ and short-wave $(0.25-2.5 \mu \mathrm{m})$ broadband are shown in Fig. 3, to clarify the magnitude of surface albedo decline. The sample size of fire counts is 9477 pixels, consistent with the sample of those marked in Fig. 2a. Surface albedo change in most fire-affected pixel changes is distributed in the negative region, while the noise in the positive region corresponds to the positive values in the north-western area in Fig. $2 b$ owing to cloud shadows. The frequency distribution of both the nearinfrared and shortwave broadband shows two apexes, which is in accordance with the spatial heterogeneity of fire in $\mathrm{AH}$ and JS. Peak values for the shortwave band are distributed between -0.02 and -0.06 , and for the near-infrared band between -0.06 and -0.10 . Since nearly half of the solar energy that reaches the surface is at wavelengths longer than $0.7 \mu \mathrm{m}$, albedo change in the near-infrared band is rather significant for the energy budget of the surface (Hartmann, 1994). Consequently, to better characterize the surface albedo decline in aspects of both spatial distribution and scope in the severely burned area, the difference of the satellite-derived surface albedo in the shortwave near-infrared band was adopted as the albedo decline between the parallel experiments over fireprone areas.

\subsection{Observational evidence on surface warming in the post-fire period}

Surface albedo is defined as the fraction of the downward solar flux density that is reflected by the surface, directly determining the absorptivity of the surface (Hartmann, 1994). In other words, when the flux of downward solar radiation reaching the surface is the same, more solar radiation will be absorbed by surface with decreased albedo. Without green 


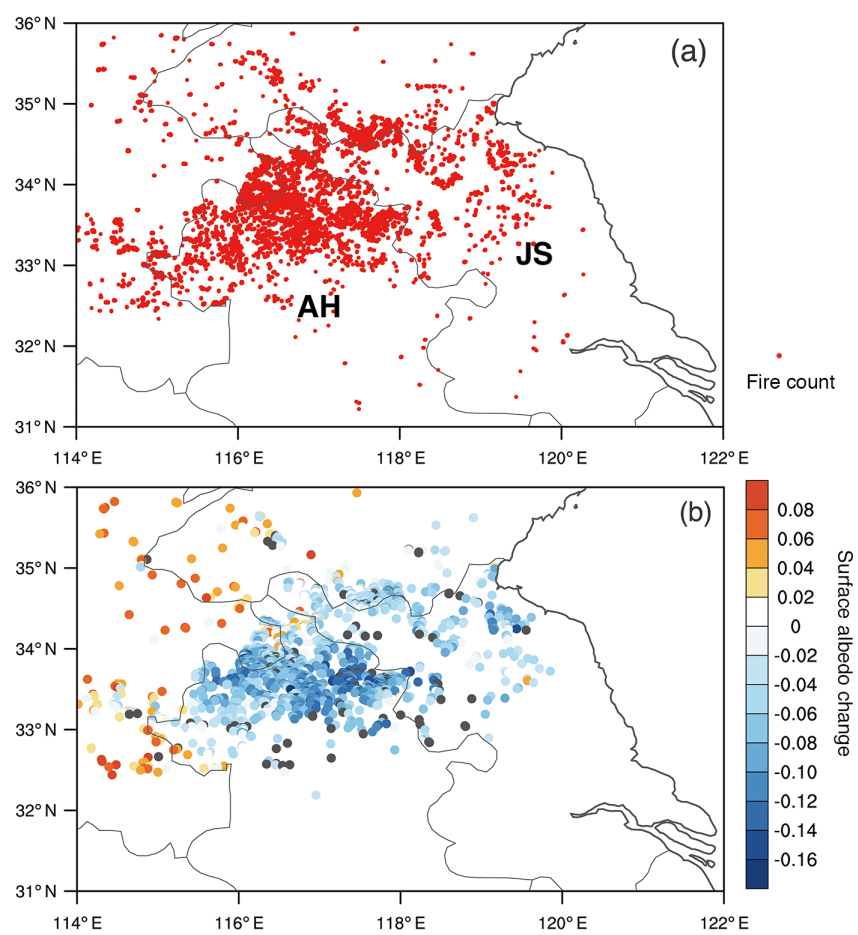

Figure 2. (a) Accumulated satellite fire counts with high-confidence from 24 May to 17 June in 2012. (b) Surface albedo changes for the period by MOD09A1 over the corresponding burned area in panel (a). Declines equal values on 17 June minus those on 24 May. Note that a certain uniform data interval was adopted considering the dots' density.

plants to photosynthesize over fire-prone areas, the immediate fire-induced increase in radiation absorption is used to heat the ground primarily and then warm the near-surface atmosphere (Andrews, 2010; Wallace and Hobbs, 2006), leading to the signal of surface warming. What is more, straw burning in YHR bursts in summer, when solar radiation is the strongest and the response of surface albedo can be the fiercest. Hence, the air temperature observations over fireprone areas after BB were investigated.

Near-surface air temperature observations at meteorological sites were compared with FNL data in 2012. Refer to Fig. 1a: burning in YHR is the most severe on 13 June, while 18 June is the end date of the wheat straw burning "season" in 2012. Temperature bias at $2 \mathrm{~m}$ height in the observational network at 20:00 LT on 13 and 18 June is shown in Fig. 4, filled according to the value of observation minus FNL. In addition, fire counts on the day and accumulated during the past $5 \mathrm{~d}$, so-called burned scars, are marked. The scattered positive values of temperature bias in Fig. 4 show that observational temperature at those sites is higher than predictions from the forecast model with only a small fraction of assimilated observations. Most sites around intensive burned scars shows a positive deviation, which is an abnormal signal of

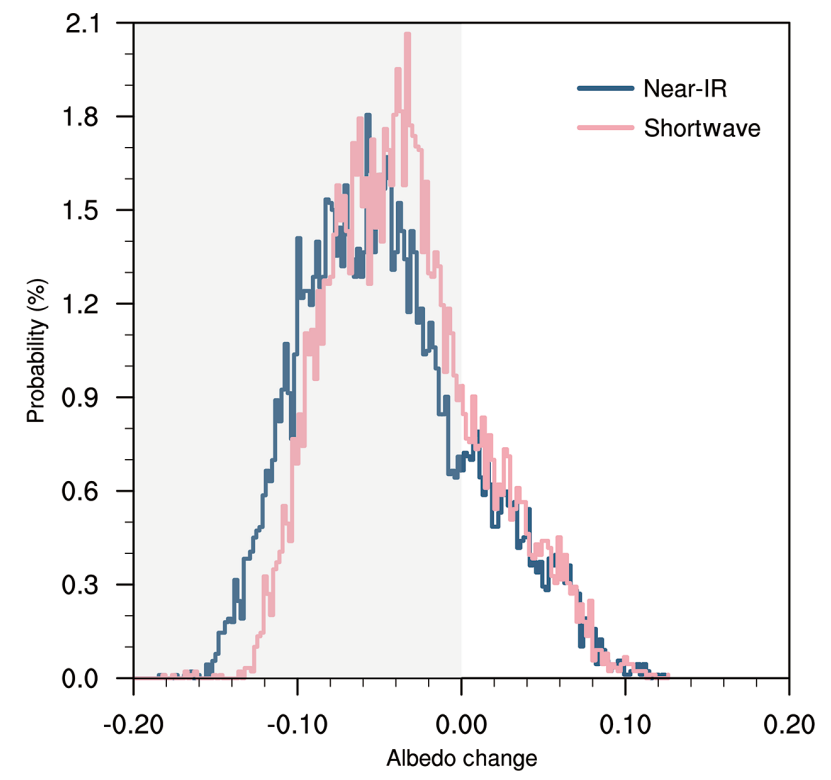

Figure 3. Frequency distributions of satellite-retrieved surface albedo changes in all pixels with highly confident satellite fire counts. Changes equal values on 17 June minus those on 24 May. The wavelength ranges of broadband "near IR" and "shortwave" are $0.7-2.5 \mu \mathrm{m}$ and $0.25-2.5 \mu \mathrm{m}$, respectively.

surface warming, extending especially in the downwind direction.

In fact, intensive straw burning occurred in YHR every June, during the post-harvest period of wheat, over the past 20 years before the launch of strict regulations in recent years (Li et al., 2016; Yin et al., 2019), which stress the significance of understanding the signals of surface warming after $\mathrm{BB}$ from the perspective of climatology.

Xuzhou (XZ) station (marked in Fig. 4), the only radiosonde observatory located in the most intensive fire-prone area in YHR. The radiosonde observations at XZ from 2007 to 2015 were compared with FNL data in the PBL. The sample of days was selected out according to burning conditions in each year and has been classified into specific statuses: pre-fire and post-fire. Post-fire days must be within $5 \mathrm{~d}$ after a severe burning, while pre-fire days must be among the $5 \mathrm{~d}$ before fire but not within $5 \mathrm{~d}$ after a previous fire. Only days under clear-sky conditions were selected. The statistical distribution of temperature bias on different isobaric levels at 20:00 LT in the two statuses is shown in Fig. 5a and b. Temperature bias was defined as the value of radiosonde observation minus FNL data. As illustrated, temperature biases are mostly positive on the lower levels in both two statuses, and absolute values of post-fire are larger than pre-fire. Combined with Fig. 5c, this means observations post-fire have a bigger positive deviation from forecast results, a signal of abnormal warming post-fire. In addition, with regards to the vertical profile of bias post-fire (Fig. 5b), deviations on lower levels tend to be bigger and more positive than those on higher 


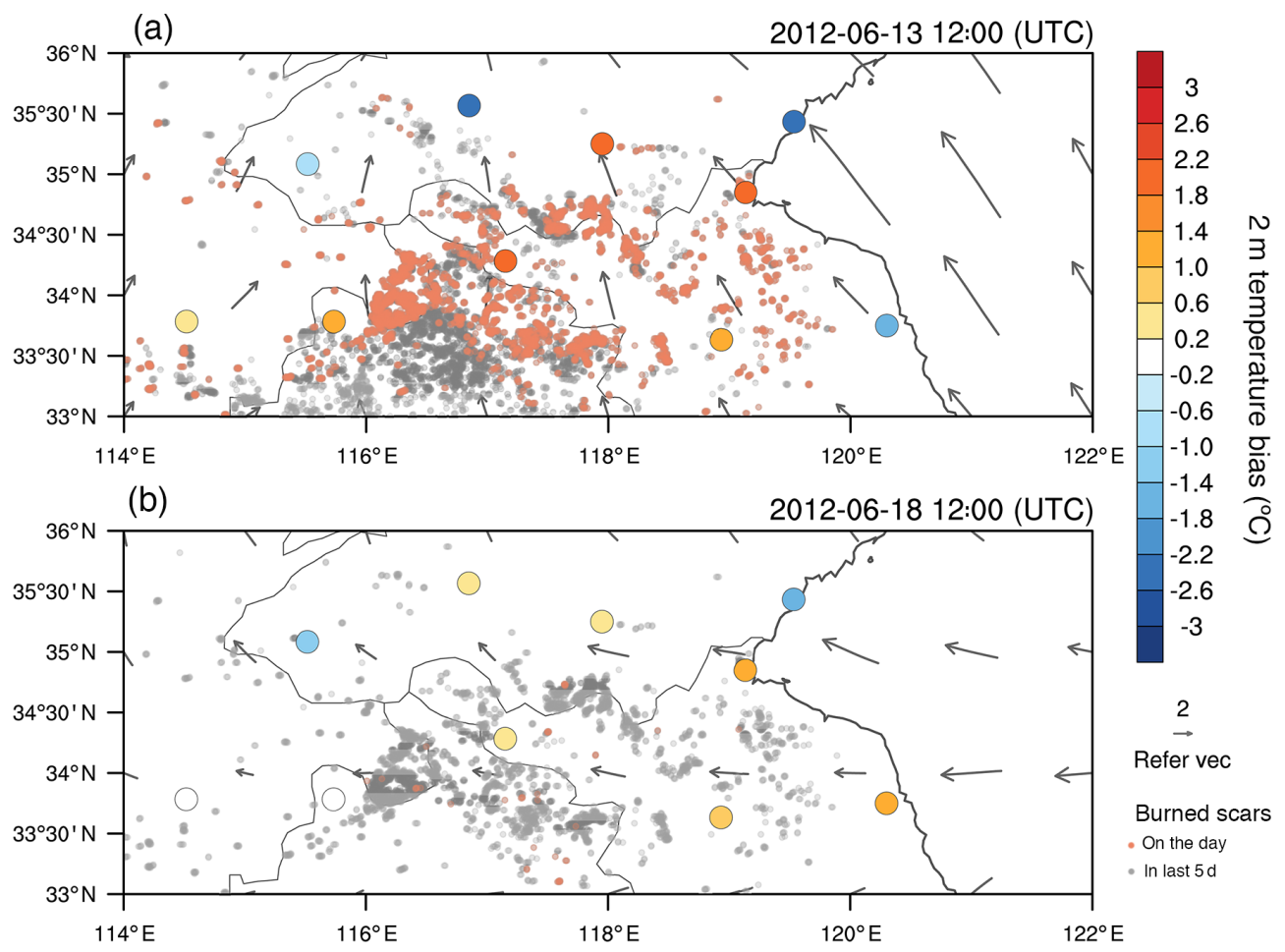

Figure 4. Temperature bias at $2 \mathrm{~m}$ height (colour-filled circles) between FNL analysis data and station observations (OBS) in YHR (a) on 13 June 2012 and (b) on 18 June 2012 at 20:00 LT. Bias is defined as the value of OBS minus FNL. Grey arrows mark the $10 \mathrm{~m}$ wind field in FNL. Grey dots mark the "burned scars", which are defined as accumulated fire counts in the past 5 d. Orange dots mark fire counts on the day. Note that the small black box in panel (a) marks the location of XZ (Xuzhou).
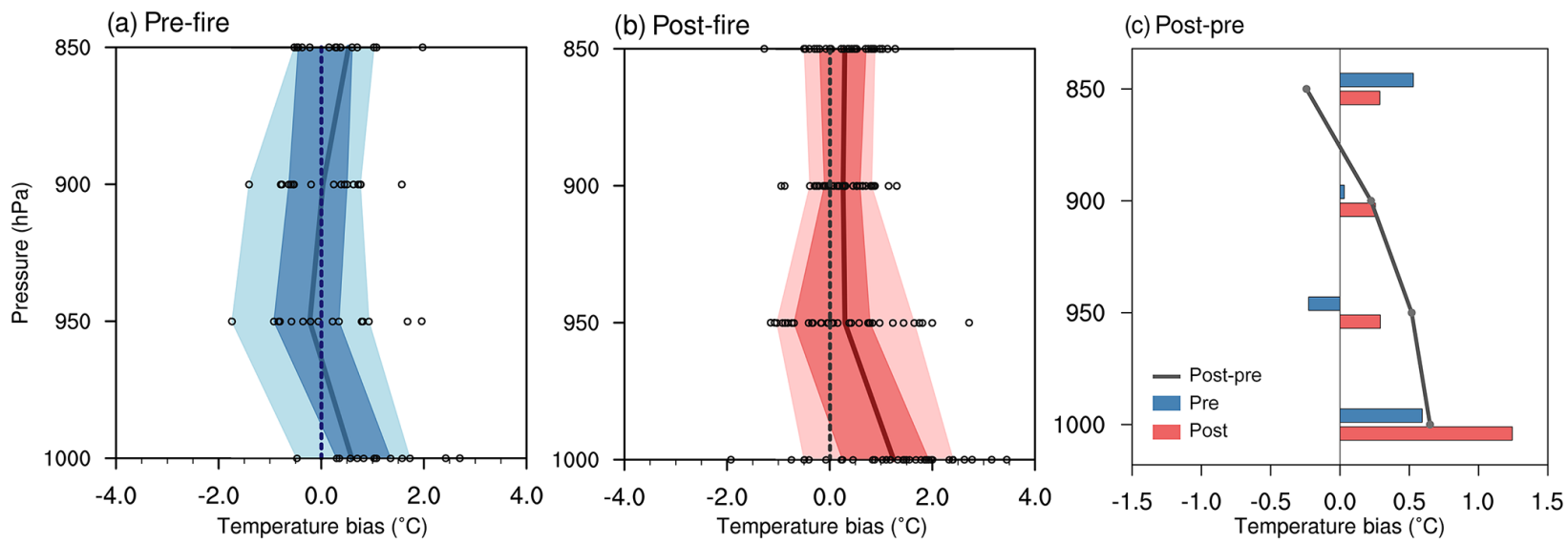

Figure 5. Temperature bias on isobaric levels between FNL analysis data and radiosonde observations (OBS) at 20:00 LT at XZ (Xuzhou) on clear-sky days before and after BB in June 2007-2015: (a) pre-fire and (b) post-fire. Black circles mark the original value of temperature bias (OBS-FNL); the dash line marks zero; and the five curves of filled parts are the 10th, 25th, 75th, and 90th percentile and the average line in proper order. Bars in panel (c) are the mean value at separate levels, and the curve is the corresponding bias between "post-fire" and "pre-fire". Note that the small black box in Fig. 4a marks the location of XZ (Xuzhou).

levels. A larger absolute value of deviation means lower predictability of temperature post-fire. Radiosonde data update 2 times a day, at 08:00 and 20:00 LT, and only patterns at 20:00 LT are shown here since no significant difference exists between the two statuses at 08:00 LT. After accumulation of absorbed radiation during the daytime, the change of thermal states near the ground level can be notable by 20:00 LT. The abnormal warming signal tends to be more obvious near the surface, which can be explained by the enhancement of surface heat absorptivity caused by decreased surface albedo. 


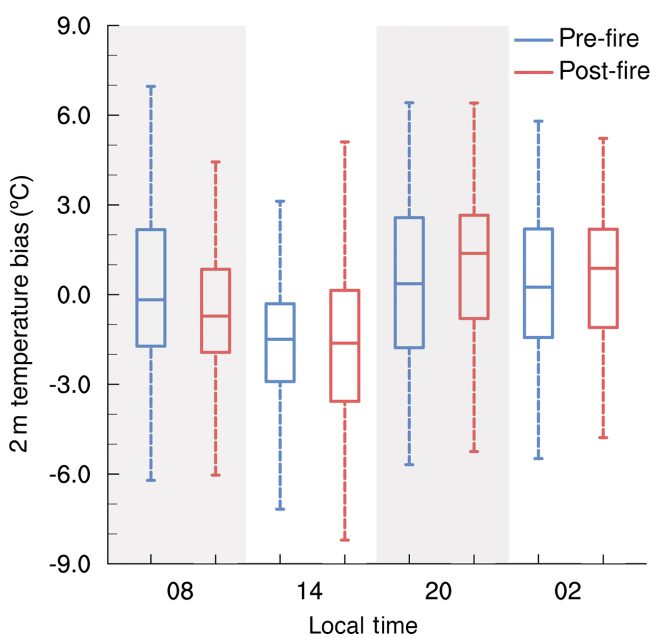

Figure 6. Temperature bias at $2 \mathrm{~m}$ height, defined as the value of OBS minus FNL, at stations over fire-prone areas at 08:00, 14:00, 20:00, and 02:00 LT under clear-sky conditions pre/post-fire in 2007-2015.

For the same sample of days in 2007-2015, the diurnal variation of $2 \mathrm{~m}$ temperature bias between site observations and FNL in the two statuses is shown in Fig. 6. Negative values of deviation at 08:00 and 14:00 LT show that FNL tends to overestimate temperature during daytime and underestimate at night. It is noteworthy that the absolute values of deviations post-fire are always larger than those pre-fire no matter during the day or night. With regard to the median values, deviations post-fire gradually surpass over those pre-fire between 14:00 and 20:00 LT, consistent with the warming signal revealed by radiosonde analysis at 20:00 LT. The continuous uptrend during the daytime demonstrates a needed response time of heat accumulation, which may be attributed to the radiative effect of surface darkening (Andrews, 2010; Myhre et al., 2005). Thus, the signal of abnormal warming becomes more apparent between 14:00 and 20:00 LT, with the gradual accumulation process.

\subsection{Improved temperature simulation by considering surface albedo change}

As mentioned earlier, fire-induced surface albedo change and observational evidence of abnormal surface warming were substantial in eastern China. However, the radiative effects on meteorology and the underlying physical images of surface warming have not been figured out yet, which should resort to model simulation. In existing studies, radiative effects of albedo changes over burned scars were investigated on land covers like boreal forests (Lyons et al., 2008) and savannas (Jin and Roy, 2005; Myhre et al., 2005), but few of them were conducted on open agricultural fire in farmlands. Exploration into the disturbance of surface albedo decline induced by agricultural BB using model simulation can be meaningful for improving weather and climate forecast of re- gions with large-scale BB events. Hence, WRF-Chem experiments targeting surface albedo change induced by agricultural BB in eastern China were conducted. The most severe episode, which happened in June 2012, was selected as the case. Surface albedo set in the two parallel experiments, CTL and ABD, is shown in Fig. 7a and b. Figure 7c shows the surface albedo difference between the two experiments, which is defined as the difference between MODIS-detect surface albedo post-fire (17 June) and pre-fire (24 May) in each grid. Model results were compared with site observational air temperature in concentrated fire-prone areas (Fig. 8a) and their southern adjacent area, YRD (Fig. 8b). In Fig. 8, the ABD experiment shows an increase in temperature and enjoys a better fit with observations at both sites in the afternoon and evening compared to the CTL experiment. Temperature anomalies can be simulated to some extent, after considering the decreased surface albedo caused by BB.

The local surface energy budget at Bengbu is shown in Fig. 9. Bengbu is located in the fire-affected area with decreased albedo. As shown in Fig. 9a, upward shortwave radiation at the surface reduces a lot, while only a little change exists in downward shortwave radiation reaching the surface. The smaller ratio of solar radiation reflected to the atmosphere by the surface can be attributed to surface albedo decline. Accordingly, with more solar radiation absorbed by the surface, the ground will be heated and the surface temperature will be higher in the ABD experiment (Fig. 9b). Higher surface temperature would give rise to larger upward heat flux, thereby heating the atmosphere near the surface by vertical mixing (Stull, 1988). So the local radiation budget change induced by surface albedo change would directly influence the near-surface air temperature and cause an abnormal warming signal over fire-prone areas in the afternoon and evening with a certain lag.

Meanwhile, the temperature influence of fire-induced albedo change is also obvious in adjacent areas like LK (Lukou) (Fig. 8b), located in YRD. Some other stations in YRD also show similar patterns. Local temperature can be affected by various factors such as local radiation budget change and advection transport caused by thermal disturbance. As illustrated in Fig. 10a, surface warming shows up in the upwind area of LK station, which indicates influence of warm advection. According to Fig. 10b and c, sharp decrease in low cloud water contents was found in the upwind area in the ABD experiment. Low clouds, effective reflectors of solar radiation (Hartmann, 1994), would cause large perturbations to the surface radiation budget. In Fig. 10d, downward shortwave radiation reaching the surface in the ABD experiment reduces quit a lot due to reflection and occlusion of low clouds. The additional heat by decreased albedo over fireprone areas would increase the surface temperature, change both sensible heat flux and latent heat flux, and then change the vertical velocity in the boundary layer and even disturb the process of cloud formation (Stull, 1988). Thus, surface albedo declines near fire locations also have great impacts on 


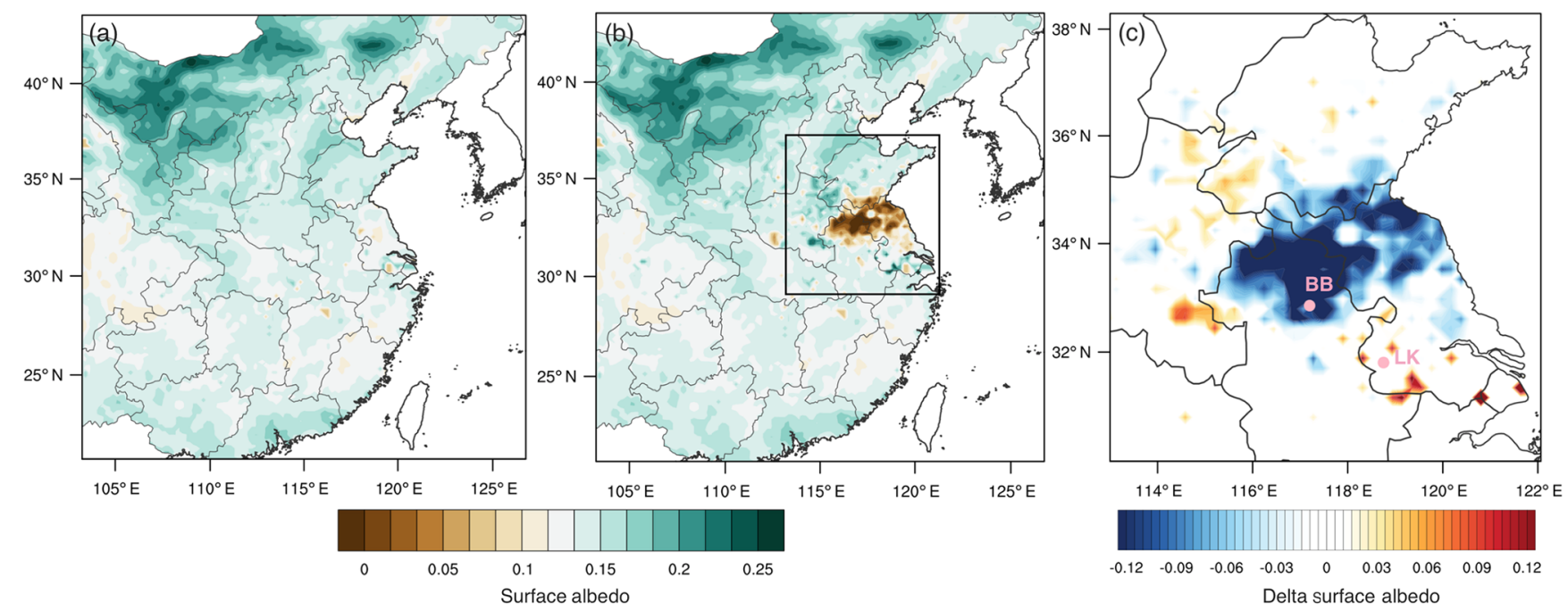

Figure 7. Surface albedo distribution in experiments (a) CTL and (b) ABD, and (c) difference between the parallel ones (ABD-CTL). Note that the region in panel (c) corresponds to the black box in panel (b).
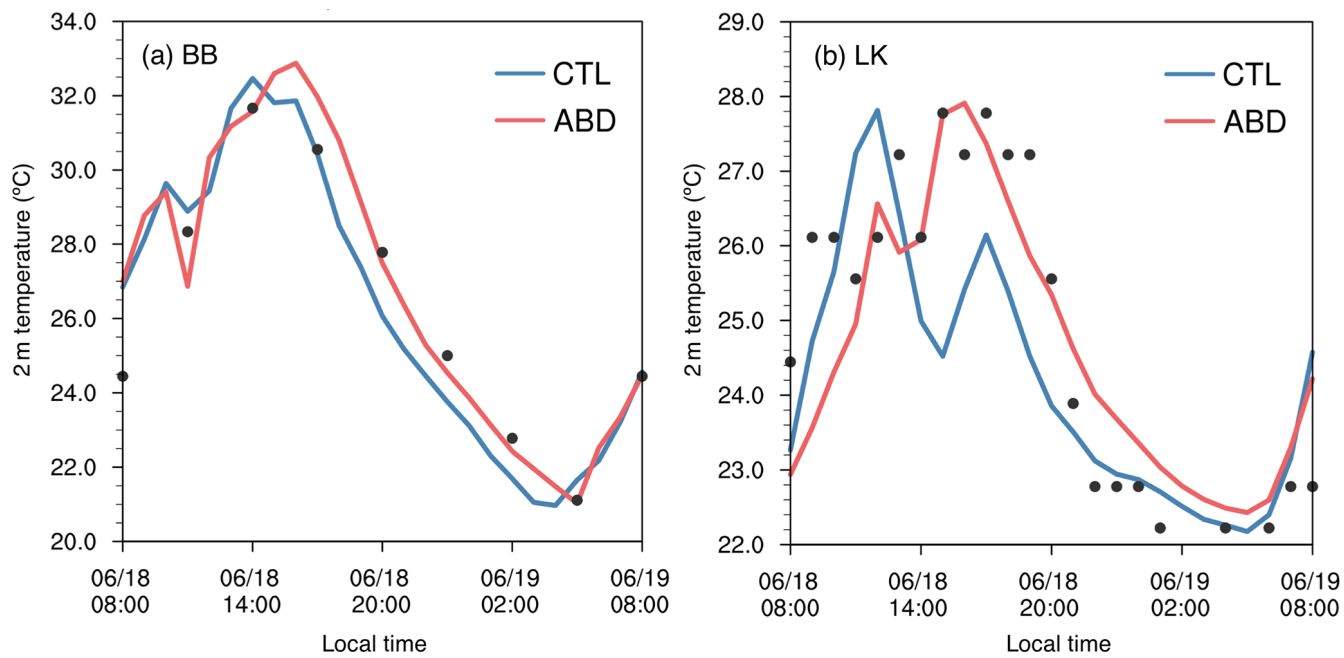

Figure 8. Simulated and observed $2 \mathrm{~m}$ temperature at meteorological stations (a) BB (Bengbu) and (b) LK (Lukou) on 18 June 2012. Note that locations of BB (Bengbu) and LK (Lukou) are marked in Fig. 7c.

areas where surface albedo was barely changed, by disturbance to cloud formation and advection transmission.

These burned scars can remain over the surface for about 1 week under rainy conditions, or even longer if dryer and calmer (Trigg and Flasse, 2000). The length of the period allows for the process of local radiative accumulation and disturbance in regional circulation, and it influences the temperature over both fire-prone areas and adjacent areas.

\section{Conclusions}

To figure out surface albedo change induced by biomass burning and its impact on regional meteorology in eastern China, an investigation into the relationship between surface albedo change and temperature anomalies was conducted based on meteorological observations and satellite retrievals, combined with WRF-Chem simulations. This study focuses on the intensive wheat straw burning that occurred every early summer in the YHR area, the major wheat-producing area in eastern China. A typical and severe burning episode in 2012 was chosen to be the study case.

Fire-induced surface darkening over fire-prone areas was verified based on satellite retrievals. A large area of surface albedo decline is shown over fire-prone areas in YHR. It also shows obvious spatial heterogeneity and has a larger decline margin in $\mathrm{AH}$, where fire counts are more concentrated and the burning is much more severe. For the near-infrared broadband, the absolute surface albedo decline ranges from -0.16 

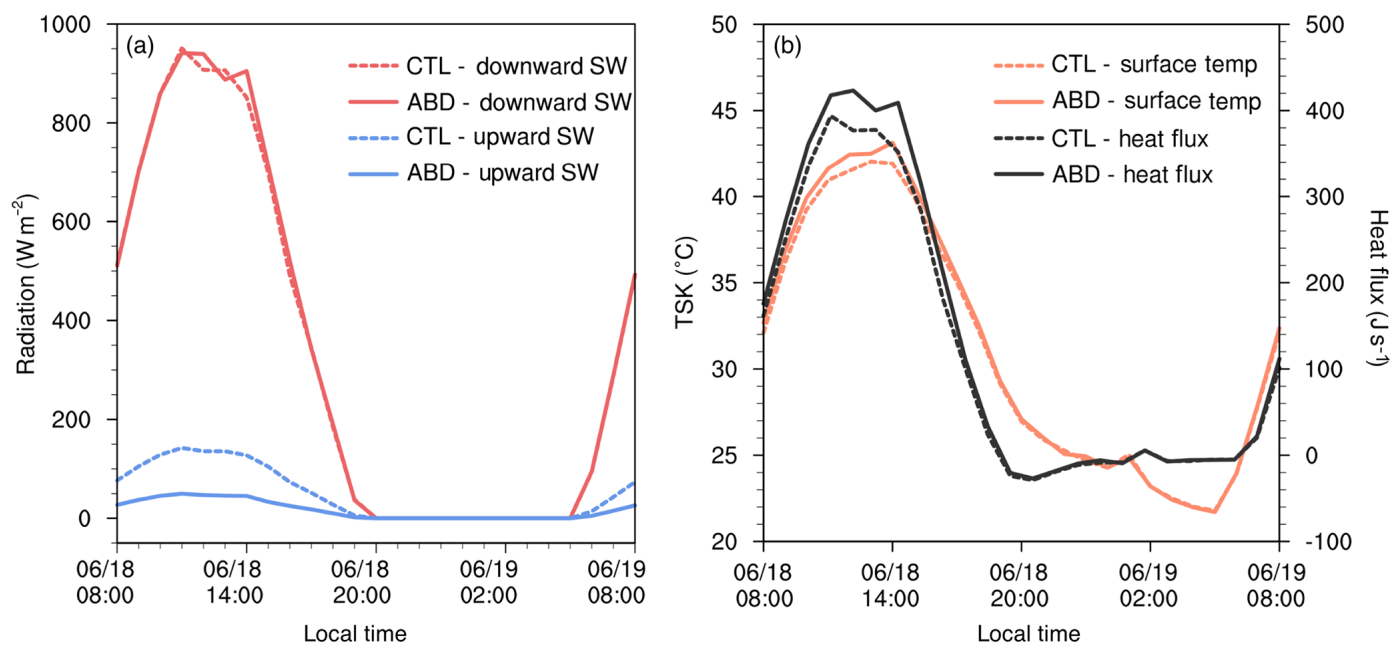

Figure 9. Thermal physical quantities at surface level on 18 June 2012 in experiments CTL and ABD. (a) Downward and upward shortwave radiation. (b) Surface temperature and upward heat flux.
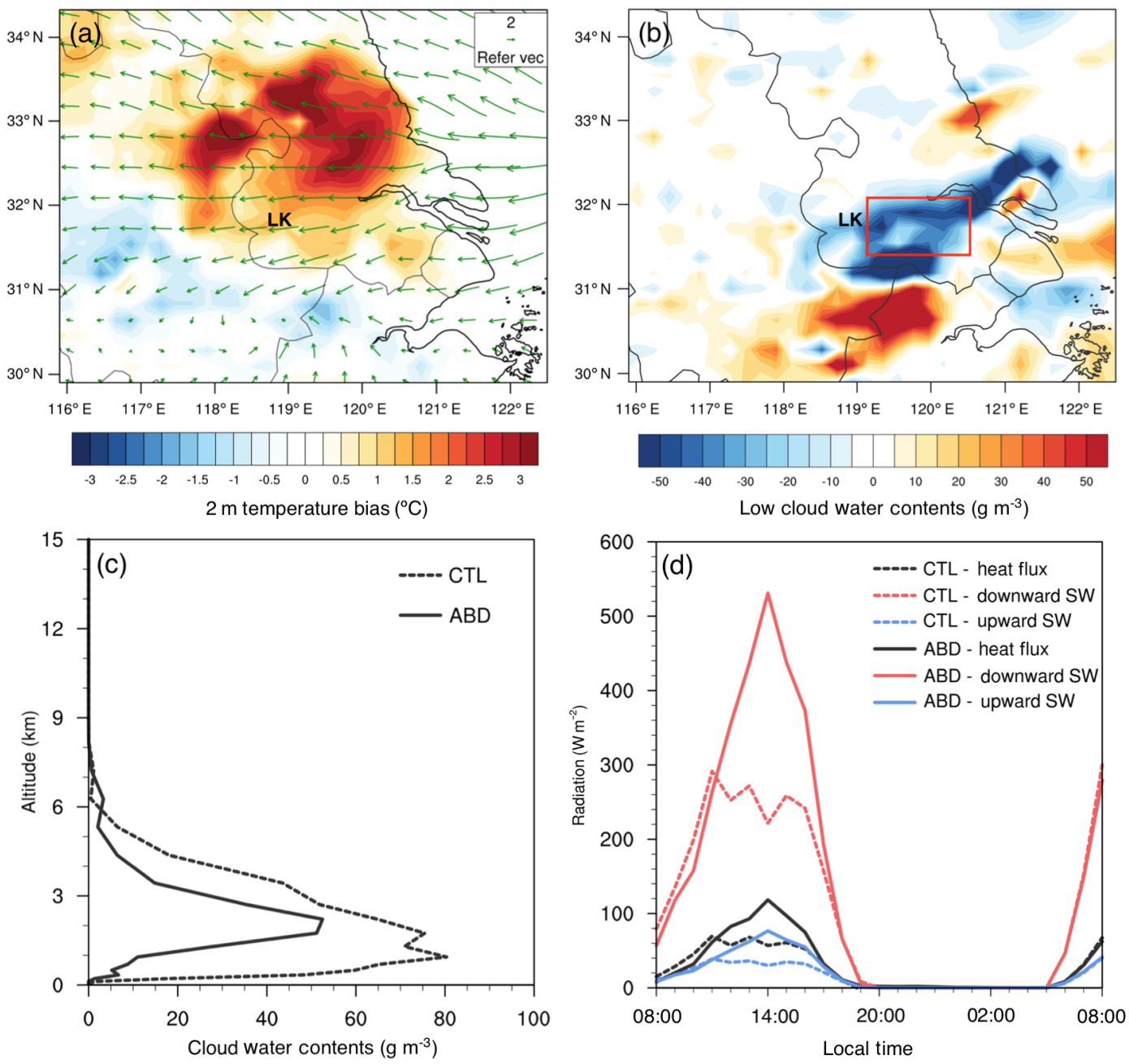

Figure 10. (a) Average $10 \mathrm{~m}$ wind field in ABD and difference of $2 \mathrm{~m}$ temperature between ABD and CTL (ABD-CTL) during the afternoon (12:00-17:00 LT) on 18 June. (b) Average difference in low cloud water contents between ABD and CTL (ABD-CTL). (c) Vertical profile of cloud water content during the afternoon (12:00-17:00 LT) and (d) shortwave radiation and upward heat flux averaged in the region marked by the red rectangle in panel (b) on 18 June. 
to -0.02 , which can be an obvious signal on a regional scale and cause large radiative disturbance. Peak values of reduction in the shortwave broadband $(0.7-2.5 \mu \mathrm{m})$ range between -0.06 and -0.02 , and those in the near-infrared broadband $(0.25-2.5 \mu \mathrm{m})$ range between -0.10 and -0.06 .

Evidence of abnormal surface warming was found in eastern China. Most sites around intensive burned scars show a positive deviation in June 2012, an abnormal signal of surface warming which extends especially in the downwind direction. Comparisons were made between the statuses of prefire and post-fire under clear-sky conditions, based on multiyear temperature observations from 2007 to 2015. Observations post-fire have a bigger positive deviation from forecast results at 20:00 LT, especially on lower levels. This kind of abnormal surface warming signal post-fire will lead to lower predictability of temperature. In terms of diurnal variation, the signal becomes more apparent between 14:00 and 20:00 LT, with the accumulation of absorbed radiation.

To explore the direct radiative effects and the potential regional meteorological impacts of surface albedo change, WRF-Chem experiments targeting the surface albedo change induced by agricultural BB in eastern China were carried out. The ABD experiment shows an increase in temperature and enjoys a better fit with observations in concentrated fire-prone areas and its southern adjacent area compared to CTL, especially in the afternoon and evening. Surface albedo change over fire-prone areas influences the surface temperature through both direct local radiation budget change and indirect disturbance in cloud formation and advection transmission.

This study shows that either human or naturally induced biomass burning will not only influence the weather and regional climate by emission of aerosols and trace gases. The change in surface albedo could also cause significant impacts at a regional scale during the post-fire periods, particular in regions with strong solar radiation. This kind of short-term disturbance should be considered in future weather, climate, and air quality forecast models.

Data availability. Meteorological datasets used in this work can be acquired from https://rda.ucar.edu/datasets/ds083.2/ (National Centers for Environmental Prediction et al., 2000), http://weather. uwyo.edu/upperair/sounding.html (University of Wyoming, 2019), and https://www7.ncdc.noaa.gov/CDO/cdoselect.cmd (Smith et al., 2011). The MODIS dataset can be obtained from the Level-1 and Atmosphere Archive \& Distribution System (LAADS) Distributed Active Archive Center (DAAC), located in the Goddard Space Flight Center in Greenbelt, Maryland (https://ladsweb.nascom.nasa. gov; Giglio and Justice, 2015a, b; Vermote, 2015).

Author contributions. RT and XH led the manuscript writing. RT and DZ conducted the data analysis and model simulations. AD contributed to the research design.
Competing interests. The authors declare that they have no conflict of interest.

Acknowledgements. The numerical modelling was conducted on computing facilities at the High Performance Computing Centering (HPCC) at Nanjing University.

Financial support. This research has been supported by the National Natural Science Foundation of China (grant nos. 91544231, 41922038,91744311 , and 41422504) and the International Cooperation project of Jiangsu Provincial Science and Technology Agency (BZ2017066).

Review statement. This paper was edited by Leiming Zhang and reviewed by three anonymous referees.

\section{References}

Abatzoglou, J. T. and Williams, A. P.: Impact of anthropogenic climate change on wildfire across western US forests, P. Natl. Acad. Sci. USA, 113, 11770-11775, https://doi.org/10.1073/pnas.1607171113, 2016.

Amiro, B. D., Orchansky, A. L., Barr, A. G., Black, T. A., Chambers, S. D., Chapin Iii, F. S., Goulden, M. L., Litvak, M., Liu, H. P., McCaughey, J. H., McMillan, A., and Randerson, J. T.: The effect of post-fire stand age on the boreal forest energy balance, Agr. Forest Meteorol., 140, 41-50, https://doi.org/10.1016/j.agrformet.2006.02.014, 2006.

Andreae, M. O.: Biomass burning - its history, use, and distribution and its impact on environmental-quality and global climate, Global Biomass Burning: Atmospheric, Climatic, and Biospheric Implications, edited by: Levine, J. S., MIT Press, Cambridge, USA, 3-21, 1991.

Andreae, M. O. and Merlet, P.: Emission of trace gases and aerosols from biomass burning, Global Biogeochem. Cy., 15, 955-966, https://doi.org/10.1029/2000gb001382, 2001.

Andrews, D. G.: An Introduction to Atmospheric Physics, Cambridge University Press, UK, 2010.

Berge, E., Huang, H. C., Chang, J., and Liu, T. H.: A study of the importance of initial conditions for photochemical oxidant modeling, J. Geophys. Res.-Atmos., 106, 1347-1363, https://doi.org/10.1029/2000jd900227, 2001.

Beringer, J., Hutley, L. B., Tapper, N. J., Coutts, A., Kerley, A., and O'Grady, A. P.: Fire impacts on surface heat, moisture and carbon fluxes from a tropical savanna in northern Australia, Int. J. Wildland Fire, 12, 333-340, https://doi.org/10.1071/wf03023, 2003.

Bowman, D. and Panton, W. J.: Fire and cyclone damage to woody vegetation on the north coast of the northern-territory, australia, Aust. Geogr., 25, 32-35, https://doi.org/10.1080/00049189408703096, 1994.

Bremer, D. J. and Ham, J. M.: Effect of spring burning on the surface energy balance in a tallgrass prairie, Agr. Forest Meteorol., 97, 43-54, https://doi.org/10.1016/s0168-1923(99)00034-9, 1999. 
Certini, G.: Effects of fire on properties of forest soils: a review, Oecologia, 143, 1-10, https://doi.org/10.1007/s00442-004-17888, 2005.

Chan, C. K. and Yao, X.: Air pollution in mega cities in China, Atmos. Environ., 42, 1-42, https://doi.org/10.1016/j.atmosenv.2007.09.003, 2008.

Chang, D. and Song, Y.: Comparison of L3JRC and MODIS global burned area products from 2000 to 2007, J. Geophys. Res., 114, D16106, https://doi.org/10.1029/2008jd011361, 2009.

Chang, D. and Song, Y.: Estimates of biomass burning emissions in tropical Asia based on satellite-derived data, Atmos. Chem. Phys., 10, 2335-2351, https://doi.org/10.5194/acp-102335-2010, 2010.

Chen, J. M., Li, C. L., Ristovski, Z., Milic, A., Gu, Y. T., Islam, M. S., Wang, S. X., Hao, J. M., Zhang, H. F., He, C. R., Guo, H., Fu, H. B., Miljevic, B., Morawska, L., Thai, P., Fat, L., Pereira, G., Ding, A. J., Huang, X., and Dumka, U. C.: A review of biomass burning: Emissions and impacts on air quality, health and climate in China, Sci. Total Environ., 579, 1000-1034, https://doi.org/10.1016/j.scitotenv.2016.11.025, 2017.

Crutzen, P. J. and Andreae, M. O.: Biomass burning in the tropics - impact on atmospheric chemistry and biogeochemical cycles, Science, 250, 1669-1678, https://doi.org/10.1126/science.250.4988.1669, 1990.

Crutzen, P. J., Heidt, L. E., Krasnec, J. P., Pollock, W. H., and Seiler, W.: Biomass burning as a source of atmospheric gases $\mathrm{CO}, \mathrm{H}_{2}, \mathrm{~N}_{2} \mathrm{O}, \mathrm{NO}, \mathrm{CH}_{3} \mathrm{Cl}$ and $\mathrm{COS}$, Nature, 282, 253-256, https://doi.org/10.1038/282253a0, 1979.

Ding, A. J., Fu, C. B., Yang, X. Q., Sun, J. N., Petäjä, T., Kerminen, V.-M., Wang, T., Xie, Y., Herrmann, E., Zheng, L. F., Nie, W., Liu, Q., Wei, X. L., and Kulmala, M.: Intense atmospheric pollution modifies weather: a case of mixed biomass burning with fossil fuel combustion pollution in eastern China, Atmos. Chem. Phys., 13, 10545-10554, https://doi.org/10.5194/acp-13-105452013, 2013a.

Ding, A. J., Fu, C. B., Yang, X. Q., Sun, J. N., Zheng, L. F., Xie, Y. N., Herrmann, E., Nie, W., Petäjä, T., Kerminen, V.-M., and Kulmala, M.: Ozone and fine particle in the western Yangtze River Delta: an overview of $1 \mathrm{yr}$ data at the SORPES station, Atmos. Chem. Phys., 13, 5813-5830, https://doi.org/10.5194/acp13-5813-2013, 2013b.

Ding, A. J., Huang, X., Nie, W., Sun, J. N., Kerminen, V. M., Petäjä, T., Su, H., Cheng, Y. F., Yang, X. Q., Wang, M. H., Chi, X. G., Wang, J. P., Virkkula, A., Guo, W. D., Yuan, J., Wang, S. Y., Zhang, R. J., Wu, Y. F., Song, Y., Zhu, T., Zilitinkevich, S., Kulmala, M., and Fu, C. B.: Enhanced haze pollution by black carbon in megacities in China, Geophys. Res. Lett., 43, 2873-2879, https://doi.org/10.1002/2016gl067745, 2016.

Duncan, B. N., Martin, R. V., Staudt, A. C., Yevich, R., and Logan, J. A.: Interannual and seasonal variability of biomass burning emissions constrained by satellite observations, J. Geophys. Res., 108, 4100, https://doi.org/10.1029/2002jd002378, 2003.

Ek, M. B., Mitchell, K. E., Lin, Y., Rogers, E., Grunmann, P., Koren, V., Gayno, G., and Tarpley, J. D.: Implementation of Noah land surface model advances in the National Centers for Environmental Prediction operational mesoscale Eta model, J. Geophys. Res.-Atmos., 108, 8851, https://doi.org/10.1029/2002jd003296, 2003.
Fearnside, P. M.: Greenhouse gas emissions from land-use change in Brazil's Amazon region, Global Climate Change and Tropical Ecosystems, edited by: Lal, R., Kimble, J. M., and Stewart, B. A., Crc Press-Taylor \& Francis Group, Boca Raton, USA, 231-249, 2000.

Gao, M., Ji, D. S., Liang, F. C., and Liu, Y.: Attribution of aerosol direct radiative forcing in China and India to emitting sectors, Atmos. Environ., 190, 35-42, https://doi.org/10.1016/j.atmosenv.2018.07.011, 2018.

Gao, X.: Analysis on the Current Status of Utilization of Crop Straw in China, Journal of Huazhong Agricultural, 354, 4031-4036, 2002.

Gatebe, C. K., Ichoku, C. M., Poudyal, R., Román, M. O., and Wilcox, E.: Surface albedo darkening from wildfires in northern sub-Saharan Africa, Environ. Res. Lett., 9, 065003, https://doi.org/10.1088/1748-9326/9/6/065003, 2014.

Giglio, L. and Justice, C.: Aqua/MODIS Level-3 Thermal Anomalies/Fire Daily Global 1km SIN Grid, NASA Level-1 and Atmosphere Archive \& Distribution System (LAADS) Distributed Active Archive Center (DAAC), G. S. F. C., Greenbelt, MD, USA, 2015a.

Giglio, L. and Justice, C.: Terra/MODIS Level-3 Thermal Anomalies/Fire Daily Global 1km SIN Grid, NASA Level-1 and Atmosphere Archive \& Distribution System (LAADS) Distributed Active Archive Center (DAAC), G. S. F. C., Greenbelt, MD, USA, $2015 b$.

Giglio, L., Loboda, T., Roy, D. P., Quayle, B., and Justice, C. O.: An active-fire based burned area mapping algorithm for the MODIS sensor, Remote Sens. Environ., 113, 408-420, https://doi.org/10.1016/j.rse.2008.10.006, 2009.

Giglio, L., Randerson, J. T., and van der Werf, G. R.: Analysis of daily, monthly, and annual burned area using the fourthgeneration global fire emissions database (GFED4), J. Geophys. Res.-Biogeo., 118, 317-328, https://doi.org/10.1002/jgrg.20042, 2013.

Giglio, L., Schroeder, W., and Justice, C. O.: The collection 6 MODIS active fire detection algorithm and fire products, Remote Sens. Environ., 178, 31-41, https://doi.org/10.1016/j.rse.2016.02.054, 2016.

Gong, P., Liu, H., Zhang, M. N., Li, C. C., Wang, J., Huang, H. B., Clinton, N., Ji, L. Y., Li, W. Y., Bai, Y., Chen, B., Xu, B., Zhu, Z., Yuan, C., Ping Suen, H., Guo, J., Xu, N., Li, W., Zhao, Y., Yang, J. N., Yu, C., Wang, X., Fu, H., Yu, L., Dronova, I., Hui, F., Cheng, X., Shi, X., Xiao, F., Liu, Q. F., and Song, L. C.: Stable classification with limited sample: transferring a 30-m resolution sample set collected in 2015 to mapping 10-m resolution global land cover in 2017, Sci. Bull., 64, 370-373, https://doi.org/10.1016/j.scib.2019.03.002, 2019.

Govaerts, Y. M., Pereira, J. M., Pinty, B., and Mota, B.: Impact of fires on surface albedo dynamics over the African continent, J. Geophys. Res., 107, 4629, https://doi.org/10.1029/2002jd002388, 2002.

Grell, G. A. and Freitas, S. R.: A scale and aerosol aware stochastic convective parameterization for weather and air quality modeling, Atmos. Chem. Phys., 14, 5233-5250, https://doi.org/10.5194/acp-14-5233-2014, 2014.

Grell, G. A., Peckham, S. E., Schmitz, R., McKeen, S. A., Frost, G., Skamarock, W. C., and Eder, B.: Fully coupled "online" chem- 
istry within the WRF model, Atmos. Environ., 39, 6957-6975, https://doi.org/10.1016/j.atmosenv.2005.04.027, 2005.

Hansen, J., Mki, S., Ruedy, R., Nazarenko, L., Lacis, A., Schmidt, G., Russell, G., Aleinov, I., Bauer, M., Bauer, S., Bell, N., Cairns, B., Canuto, V., Chandler, M., Cheng, Y., Delgenio, A., Faluvegi, G., Fleming, E., Friend, A., and Zhang, S.: Efficacy of climate forcings, J. Geophys. Res., 110, D18104, https://doi.org/10.1029/2005JD005776, 2005.

Hao, W. M. and Liu, M.: Spatial and temporal distribution of tropical biomass burning, Global Biogeochem. Cy., 8, 495-503, https://doi.org/10.1029/94gb02086, 1994.

Hartmann, D. L.: Global Physical Climatology, Phys. Sci., Academic Press, America, Cambridge, Massachusetts, USA, 1994.

Hawbaker, T. J., Radeloff, V. C., Syphard, A. D., Zhu, Z. L., and Stewart, S. I.: Detection rates of the MODIS active fire product in the United States, Remote Sens. Environ., 112, 2656-2664, https://doi.org/10.1016/j.rse.2007.12.008, 2008.

Haywood, J. M. and Ramaswamy, V.: Global sensitivity studies of the direct radiative forcing due to anthropogenic sulfate and black carbon aerosols, J. Geophys. Res.-Atmos., 103, 60436058, https://doi.org/10.1029/97jd03426, 1998.

He, L. M., Wang, W. J., Wang, Q., Wei, B., Li, Q., Wang, C. Z., and Liu, X. M.: Evaluation of the Agricultural Residues Burning Reduction in China Using MODIS Fire Product, Environmental Monitoring in China, 23, 42-50, 2007.

Hobbs, P. V., Reid, J. S., Kotchenruther, R. A., Ferek, R. J., and Weiss, R.: Direct radiative forcing by smoke from biomass burning, Science, 275, 1776-1778, 1997.

Huang, X., Li, M. M., Li, J. F., and Song, Y.: A high-resolution emission inventory of crop burning in fields in China based on MODIS Thermal Anomalies/Fire products, Atmos. Environ., 50, 9-15, https://doi.org/10.1016/j.atmosenv.2012.01.017, 2012a.

Huang, X., Song, Y., Li, M. M., Li, J. F., and Zhu, T.: Harvest season, high polluted season in East China, Environ. Res. Lett., 7, 044033, https://doi.org/10.1088/1748-9326/7/4/044033, 2012b.

Huang, X., Ding, A., Liu, L., Liu, Q., Ding, K., Niu, X., Nie, W., Xu, Z., Chi, X., Wang, M., Sun, J., Guo, W., and Fu, C.: Effects of aerosol-radiation interaction on precipitation during biomassburning season in East China, Atmos. Chem. Phys., 16, 1006310082, https://doi.org/10.5194/acp-16-10063-2016, 2016.

Huang, X., Wang, Z. L., and Ding, A. J.: Impact of AerosolPBL Interaction on Haze Pollution: Multiyear Observational Evidences in North China, Geophys. Res. Lett., 45, 8596-8603, https://doi.org/10.1029/2018gl079239, 2018.

Iacono, M. J., Delamere, J. S., Mlawer, E. J., Shephard, M. W., Clough, S. A., and Collins, W. D.: Radiative forcing by long-lived greenhouse gases: Calculations with the AER radiative transfer models, J. Geophys. Res., 113, D13103, https://doi.org/10.1029/2008jd009944, 2008.

Janjic, Z. I.: The Step-Mountain Eta Coordinate Model - Further Developments Of The Convection, Viscous Sublayer, And Turbulence Closure Schemes, Mon. Weather Rev., 122, 927-945, https://doi.org/10.1175/15200493(1994)122<0927:Tsmecm>2.0.Co;2, 1994.

Jin, Y. and Roy, D. P.: Fire-induced albedo change and its radiative forcing at the surface in northern Australia, Geophys. Res. Lett., 32, L13401, https://doi.org/10.1029/2005gl022822, 2005.

Kaiser, J. W., Heil, A., Andreae, M. O., Benedetti, A., Chubarova, N., Jones, L., Morcrette, J.-J., Razinger, M., Schultz, M. G.,
Suttie, M., and van der Werf, G. R.: Biomass burning emissions estimated with a global fire assimilation system based on observed fire radiative power, Biogeosciences, 9, 527-554, https://doi.org/10.5194/bg-9-527-2012, 2012.

Langmann, B., Duncan, B., Textor, C., Trentmann, J., and Van Der Werf, G. R.: Vegetation fire emissions and their impact on air pollution and climate, Atmos. Environ., 43, 107-116, https://doi.org/10.1016/j.atmosenv.2008.09.047, 2009.

Laurent, P., Mouillot, F., Moreno, M. V., Yue, C., and Ciais, P.: Varying relationships between fire radiative power and fire size at a global scale, Biogeosciences, 16, 275-288, https://doi.org/10.5194/bg-16-275-2019, 2019.

Lei, L. G. and Yuan, H. M.: China Agricultural Statistical Yearbook 2013, China Agricultural Press, Beijing, China, 2013.

Li, J., Bo, Y., and Xie, S. D.: Estimating emissions from crop residue open burning in China based on statistics and MODIS fire products, J. Environ. Sci., 44, 158-170, https://doi.org/10.1016/j.jes.2015.08.024, 2016.

Li, M., Zhang, Q., Kurokawa, J.-I., Woo, J.-H., He, K., Lu, Z., Ohara, T., Song, Y., Streets, D. G., Carmichael, G. R., Cheng, Y., Hong, C., Huo, H., Jiang, X., Kang, S., Liu, F., Su, H., and Zheng, B.: MIX: a mosaic Asian anthropogenic emission inventory under the international collaboration framework of the MICS-Asia and HTAP, Atmos. Chem. Phys., 17, 935-963, https://doi.org/10.5194/acp-17-935-2017, 2017.

Liang, S. L.: Narrowband to broadband conversions of land surface albedo I, Remote Sens. Environ., 76, 213-238, https://doi.org/10.1016/s0034-4257(00)00205-4, 2001.

Liang, S. L., Shuey, C. J., Russ, A. L., Fang, H. L., Chen, M. Z., Walthall, C. L., Daughtry, C. S. T., and Hunt, R.: Narrowband to broadband conversions of land surface albedo: II. Validation, Remote Sens. Environ., 84, 25-41, https://doi.org/10.1016/s00344257(02)00068-8, 2003.

Lin, Y. L., Farley, R. D., and Orville, H. D.: Bulk Parameterization Of The Snow Field In A Cloud Model, J. Clim. Appl. Meteorol., 22, 1065-1092, https://doi.org/10.1175/15200450(1983)022<1065:Bpotsf>2.0.Co;2, 1983.

Lo, J. C. F., Yang, Z. L., and Pielke, R. A.: Assessment of three dynamical climate downscaling methods using the Weather Research and Forecasting (WRF) model, J. Geophys. Res.-Atmos., 113, D09112, https://doi.org/10.1029/2007jd009216, 2008.

Lu, B., Kong, S. F., Han, B., Wang, X. Y., and Bai, Z. P.: Inventory of atmospheric pollutants discharged from biomass burning in China continent in 2007, China Environmental Science, 31, 186194, 2011.

Lyons, E. A., Jin, Y. F., and Randerson, J. T.: Changes in surface albedo after fire in boreal forest ecosystems of interior Alaska assessed using MODIS satellite observations, J. Geophys. Res.Biogeo., 113, G02012, https://doi.org/10.1029/2007jg000606, 2008.

Marlon, J. R., Bartlein, P. J., Carcaillet, C., Gavin, D. G., Harrison, S. P., Higuera, P. E., Joos, F., Power, M. J., and Prentice, I. C.: Erratum: Climate and human influences on global biomass burning over the past two millennia, Nat. Geosci., 2, 307-307, https://doi.org/10.1038/ngeo468, 2009.

Mlawer, E. J., Taubman, S. J., Brown, P. D., Iacono, M. J., and Clough, S. A.: Radiative transfer for inhomogeneous atmospheres: RRTM, a validated correlated-k model for 
the longwave, J. Geophys. Res.-Atmos., 102, 16663-16682, https://doi.org/10.1029/97jd00237, 1997.

Myhre, G., Govaerts, Y., Haywood, J. M., and K., B. T.: Radiative effect of surface albedo change from biomass burning, Geophys. Res. Lett., 32, L20812, https://doi.org/10.1029/2005gl022897, 2005.

National Centers for Environmental Prediction/National Weather Service/NOAA/U.S. Department of Commerce: NCEP FNL Operational Model Global Tropospheric Analyses, available at: https://rda.ucar.edu/datasets/ds083.2/ (last access: 31 Decemeber 2019), 2000.

Nie, W., Ding, A. J., Xie, Y. N., Xu, Z., Mao, H., Kerminen, V.-M., Zheng, L. F., Qi, X. M., Huang, X., Yang, X.Q., Sun, J. N., Herrmann, E., Petäjä, T., Kulmala, M., and Fu, C. B.: Influence of biomass burning plumes on HONO chemistry in eastern China, Atmos. Chem. Phys., 15, 1147-1159, https://doi.org/10.5194/acp-15-1147-2015, 2015.

Nolan, R. H., Boer, M. M., Collins, L., Resco De Dios, V., Clarke, H., Jenkins, M., Kenny, B., and Bradstock, R. A.: Causes and consequences of eastern Australia's 201920 season of mega-fires, Glob. Change Biol., 26, 1039-1041, https://doi.org/10.1111/gcb.14987, 2020.

Pechony, O. and Shindell, D. T.: Driving forces of global wildfires over the past millennium and the forthcoming century, P. Natl. Acad. Sci. USA, 107, 19167-19170, https://doi.org/10.1073/pnas.1003669107, 2010.

Pereira, J. M. C., Sá, A. C. L., Sousa, A. M. O., Silva, J. M. N., Santos, T. N., and Carreiras, J. M. B.: Spectral characterisation and discrimination of burnt areas, in: Remote Sensing of Large Wildfires, edited by: Chuvieco, E., Springer, Berlin, Heidelberg, 123-138, https://doi.org/10.1007/978-3-642-60164-4_7, 1999.

Podgorny, I. A., Li, F., and Ramanathan, V.: Large Aerosol Radiative Forcing due to the 1997 Indonesian Forest Fire, Geophys. Res. Lett., 30, 1028, https://doi.org/10.1029/2002gl015979, 2003.

Randerson, J. T., Chen, Y., van der Werf, G. R., Rogers, B. M., and Morton, D. C.: Global burned area and biomass burning emissions from small fires, J. Geophys. Res.-Biogeo., 117, G04012, https://doi.org/10.1029/2012jg002128, 2012.

Ravindra, K., Singh, T., Mor, S., Singh, V., Mandal, T. K., Bhatti, M. S., Gahlawat, S. K., Dhankhar, R., Mor, S., and Beig, G.: Realtime monitoring of air pollutants in seven cities of North India during crop residue burning and their relationship with meteorology and transboundary movement of air, Sci. Total Environ., 690, 717-729, https://doi.org/10.1016/j.scitotenv.2019.06.216, 2019.

Roy, D. P. and Landmann, T.: Characterizing the surface heterogeneity of fire effects using multi-temporal reflective wavelength data, Int. J. Remote Sens., 26, 4197-4218, https://doi.org/10.1080/01431160500112783, 2005.

Schaaf, C. B., Gao, F., Strahler, A. H., Lucht, W., Li, X. W., Tsang, T., Strugnell, N. C., Zhang, X. Y., Jin, Y. F., Muller, J., Lewis, P., Barnsley, M., Hobson, P., Disney, M., Roberts, G., Dunderdale, M., Doll, C., D'Entremont, R. P., Hu, B., Liang, S., Privette, J. L., and Roy, D.: First operational BRDF, albedo nadir reflectance products from MODIS, Remote Sens. Environ., 83, 135-148, https://doi.org/10.1016/s0034-4257(02)00091-3, 2002.

Smith, A., Lott, N., and Vose, R.: The Integrated Surface Database, National Centers for Environmental Information (NCEI), avail- able at: https://www.ncdc.noaa.gov/isd (last access: 10 April 2020), 2011.

Streets, D. G., Yarber, K. F., Woo, J. H., and Carmichael, G. R.: Biomass burning in Asia: Annual and seasonal estimates and atmospheric emissions, Global Biogeochem. Cy., 17, 1099, https://doi.org/10.1029/2003gb002040, 2003.

Stull, R. B.: An introduction to boundary layer meteorology, Atmospheric Sciences Library, Springer, Dordrecht, the Netherlands, 89 pp., 1988.

Thompson, A. M.: Biomass burning and the atmosphere - accomplishments and research opportunities, Atmos. Environ., 30, R1R2, https://doi.org/10.1016/s1352-2310(96)90021-7, 1996.

Tipayarom, A. and Kim Oanh, N. T.: Influence of rice straw open burning on levels and profiles of semi-volatile organic compounds in ambient air, Chemosphere, 243, 125379, https://doi.org/10.1016/j.chemosphere.2019.125379, 2020.

Trigg, S. and Flasse, S.: Characterizing the spectral-temporal response of burned savannah usingin situspectroradiometry and infrared thermometry, Int. J. Remote Sens., 21, 3161-3168, https://doi.org/10.1080/01431160050145045, 2000.

Tsuyuzaki, S., Kushida, K., and Kodama, Y.: Recovery of surface albedo and plant cover after wildfire in a Picea mariana forest in interior Alaska, Climatic Change, 93, 517-525, https://doi.org/10.1007/s10584-008-9505-y, 2008.

Uhl, C. and Kauffman, J. B.: Deforestation, fire susceptibility, and potential tree responses to fire in the eastern amazon, Ecology, 71, 437-449, https://doi.org/10.2307/1940299, 1990.

University of Wyoming: Upper airdata of soundings, Department of Atmospheric science, University of Wyoming, available at: http://weather.uwyo.edu/upperair/sounding.html, last access: 28 December 2019.

van der Werf, G. R., Randerson, J. T., Giglio, L., Collatz, G. J., Kasibhatla, P. S., and Arellano Jr., A. F.: Interannual variability in global biomass burning emissions from 1997 to 2004, Atmos. Chem. Phys., 6, 3423-3441, https://doi.org/10.5194/acp-6-34232006, 2006.

van der Werf, G. R., Randerson, J. T., Giglio, L., Collatz, G. J., Mu, M., Kasibhatla, P. S., Morton, D. C., DeFries, R. S., Jin, Y., and van Leeuwen, T. T.: Global fire emissions and the contribution of deforestation, savanna, forest, agricultural, and peat fires (1997-2009), Atmos. Chem. Phys., 10, 11707-11735, https://doi.org/10.5194/acp-10-11707-2010, 2010.

Veraverbeke, S., Verstraeten, W. W., Lhermitte, S., Van De Kerchove, R., and Goossens, R.: Assessment of post-fire changes in land surface temperature and surface albedo, and their relation with fire - burn severity using multitemporal MODIS imagery, Int. J. Wildland Fire, 21, 243-256, https://doi.org/10.1071/wf10075, 2012.

Vermote, E.: MODIS Level-3 (L3) Land Surface Reflectance (LSR), NASA Level-1 and Atmosphere Archive \& Distribution System (LAADS) Distributed Active Archive Center (DAAC), G. S. F. C., Greenbelt, MD, USA, 2015.

Wallace, J. M. and Hobbs, P. V.: Atmospheric Science, 2nd edn., Academic Press, Cambridge, Massachusetts, USA, 2006.

Wang, Z., Huang, X., and Ding, A.: Dome effect of black carbon and its key influencing factors: a one-dimensional modelling study, Atmos. Chem. Phys., 18, 2821-2834, https://doi.org/10.5194/acp-18-2821-2018, 2018. 
Wiedinmyer, C., Akagi, S. K., Yokelson, R. J., Emmons, L. K., AlSaadi, J. A., Orlando, J. J., and Soja, A. J.: The Fire INventory from NCAR (FINN): a high resolution global model to estimate the emissions from open burning, Geosci. Model Dev., 4, 625641, https://doi.org/10.5194/gmd-4-625-2011, 2011.

Xie, Y. N., Ding, A. J., Nie, W., Mao, H. T., Qi, X. M., Huang, X., Xu, Z., Kerminen, V. M., Petäjä, T., Chi, X. G., Virkkula, A., Boy, M., Xue, L. K., Guo, J., Sun, J. N., Yang, X. Q., Kulmala, M., and Fu, C. B.: Enhanced sulfate formation by nitrogen dioxide: Implications from in situ observations at the SORPES station, J. Geophys. Res.-Atmos., 120, 12679-12694, https://doi.org/10.1002/2015jd023607, 2015.

Xu, Z. N., Huang, X., Nie, W., Shen, Y. C., Zheng, L. F., Xie, Y. N., Wang, T. Y., Ding, K., Liu, L. X., Zhou, D. R., Qi, X. M., and Ding, A. J.: Impact of Biomass Burning and Vertical Mixing of Residual-Layer Aged Plumes on Ozone in the Yangtze River Delta, China: A TetheredBalloon Measurement and Modeling Study of a Multiday Ozone Episode, J. Geophys. Res.-Atmos., 123, 11786-11803, https://doi.org/10.1029/2018jd028994, 2018.

Yan, X. Y., Ohara, T., and Akimoto, H.: Bottom-up estimate of biomass burning in mainland China, Atmos. Environ., 40, 52625273, https://doi.org/10.1016/j.atmosenv.2006.04.040, 2006.

Yang, S. J., He, H. P., Lu, S. L., Chen, D., and Zhu, J. X.: Quantification of crop residue burning in the field and its influence on ambient air quality in Suqian, China, Atmos. Environ., 42, 19611969, https://doi.org/10.1016/j.atmosenv.2007.12.007, 2008.

Yang, Y. J., Fu, Y. F., Wu, B. W., Shi, C. E., Deng, X. L., Zhang, H., and Zhang, Y.: Impacts of Agricultural Fire on Aerosol Distribution over East China During Summer Harvest Time, Journal of Atmospheric and Environmenal Optics, 8, 241-252, https://doi.org/10.3969/j.issn.1673-6141.2013.04.001, 2013.
Yang, Y. J., Yim, S. H. L., Haywood, J., Osborne, M., Chan, J. C. S., Zeng, Z. L., and Cheng, J. C. H.: Characteristics of Heavy Particulate Matter Pollution Events Over Hong Kong and Their Relationships With Vertical Wind Profiles Using High-Time-Resolution Doppler Lidar Measurements, J. Geophys. Res.-Atmos., 124, 9609-9623, https://doi.org/10.1029/2019JD031140, 2019.

Yin, L., Du, P., Zhang, M., Liu, M., Xu, T., and Song, Y.: Estimation of emissions from biomass burning in China (2003-2017) based on MODIS fire radiative energy data, Biogeosciences, 16, 16291640, https://doi.org/10.5194/bg-16-1629-2019, 2019.

Zhang, Y., Ding, A. J., Mao, H. T., Nie, W., Zhou, D. R., Liu, L. X., Huang, X., and $\mathrm{Fu}, \mathrm{C}$. B.: Impact of synoptic weather patterns and inter-decadal climate variability on air quality in the North China Plain during 1980-2013, Atmos. Environ., 124, 119-128, https://doi.org/10.1016/j.atmosenv.2015.05.063, 2016.

Zhou, D., Ding, K., Huang, X., Liu, L., Liu, Q., Xu, Z., Jiang, F., Fu, C., and Ding, A.: Transport, mixing and feedback of dust, biomass burning and anthropogenic pollutants in eastern Asia: a case study, Atmos. Chem. Phys., 18, 16345-16361, https://doi.org/10.5194/acp-18-16345-2018, 2018.

Zhu, X., Yun, X., Meng, W., Xu, H., Du, W., Shen, G., Cheng, H., Ma, J., and Tao, S.: Stacked Use and Transition Trends of Rural Household Energy in Mainland China, Environ. Sci. Technol., 53, 521-529, https://doi.org/10.1021/acs.est.8b04280, 2019. 